RACIC 5 (2) (2020)
UNIIVERITAS
ABDURRAB
Ittp:/jurnal.univrab.ac.id/index.php/racic

\title{
ANALISIS FAKTOR PENYEBAB KETERLAMBATAN PELAKSANAAN PROYEK REHABILITASI SEKOLAH DALAM MASAPANDEMI COVID-19
}

\author{
Gusni Vitri ${ }^{1}$ Wendi Boy ${ }^{2}$ Wiwin Putri Zayu ${ }^{3}$ \\ ${ }^{1,2,3}$ Program Studi Teknik Sipil Universitas Dharma Andalas \\ Jl. Sawahan No. 103 A Simpang Haru, Padang, Indonesia \\ email : vitri.gusni@gmail.com \\ email : wendiboy92@gmail.com \\ email : winzayu@gmail.com
}

\section{Info Artikel \\ Sejarah Artikel: \\ Diterima November 2020 \\ Disetujui Desember 2020 \\ Dipublikasikan Desember 2020}

Keywords : Keterlambatan Proyek, Pandemi Covid-19, Rehabilitasi Sekolah, Kontrak Konstruksi

\begin{abstract}
Abstrak
Pelaksanaan proyek konstruksi membutuhkan sumberdaya material, tenaga kerja, peralatan, metoda dan modal untuk mencapai tujuan proyek, yaitu tepat waktu, tepat mutu serta sesuai dengan biaya yang di rencanakan. Berbagai faktor internal dan eksternal berpengaruh selama pelaksanaan proyek. Kondisi pandemi covid-19 yang terjadi di Indonesia dan seluruh dunia menjadi salah satu faktor yang menghambat penyelesaian proyek. Proyek Rehabilitasi Sekolah Dasar di Kabupaten Pasaman Barat tersebar di 15 (lima belas) lokasi di semua kecamatan. Proyek sudah terkontrak di awal tahun 2020, sebelum wabah covid-19 marak terjadi. Proyek ini mengalami keterlambatan dengan melakukan 2 (dua) kali addendum perpanjangan waktu pelaksanaan. Penelitian ini bersifat deskriptif kuantitatif dan kualitatif. Pengumpulan data dilakukan melalui kuisioner dan wawancara langsung kepada responden yaitu kontraktor, konsultan MK dan Owner (KemenPUPR Satker PPIP2B Prov. Sumbar). Hasil penelitian menunjukkan bahwa penyebab keterlambatan proyek yang paling dominan adalah Kejadian yang Tidak Terduga (Force Majeure), Kebijakan Pemerintah, Desain. Keterlambatan juga di pengaruhi oleh faktor lain, yaitu Cuaca, Karakteristik Tempat dan Material.
\end{abstract}

Kata Kunci: Keterlambatan Proyek, Pandemi Covid-19, Rehabilitasi Sekolah, Kontrak Konstruksi

\begin{abstract}
Implementation of construction projects requires resources of materials, labors, equipments, methods and capital to achieve project objectives, namely on time, on quality and according to planned costs. Various internal and external factors influence during project implementation. The conditions of the Covid-19 pandemic that occurred in Indonesia and the world were one of the factors inhibiting project completion. The Primary School Rehabilitation Project in West Pasaman Regency is spread over 15 (fifteen) locations in all sub-districts. The project was contracted in early 2020, before the Covid-19 outbreak erupted. This project has been delayed due to the implementation with 2 (two) addendums to extend the implementation time. This research is descriptive quantitative and qualitative. The data was collected through questionnaires and direct interviews with respondents, namely contractors, consultants for the Constitutional Court and the Owner (KemenPUPR Satker PPIP2B West Sumatra Province). The results showed that the most dominant cause of project delays was Force
\end{abstract}


Majeure, Government Policy, Design. The delay is also influenced by other factors, namely weather, place characteristics and materials.

Keywords: Project Delays, Covid-19 Pandemic, School Rehabilitation, Construction Contract

(c) 2020 Universitas Abdurrab

Alamat korespondensi:

Program Studi Teknik Sipil

ISSN 2527-7073

Universitas Dharma Andalas

Jl. Sawahan No. 103 A

Simpang Haru, Padang, Indonesia

email : vitri.gusni@gmail.com

\section{PENDAHULUAN}

Salah satu industri yang sedang berkembang di Indonesia adalah proyek konstruksi. Peningkatan mutu dan ragam jenis infrastruktur dilaksanakan setip tahunnya. Dalam pelaksanaan proyek konstruksi dibutuhkan sumberdaya seperti: material, tenaga kerja, peralatan, metoda dan modal untuk mencapai tujuan proyek, yaitu tepat waktu, tepat mutu serta sesuai dengan biaya yang di rencanakan. Ada banyak faktor internal dan eksternal yang mempengaruhi tercapainya tujuan proyek konstruksi. Salah satu permasalahan dalam pelaksanaan proyek konstruksi adalah keterlambatan waktu yang menyebabkan terjadinya addendum. Faktor-faktor yang menyebabkan keterlambatan proyek antara lain bersumber dari faktor manajerial, tenaga kerja, keuangan, kebijakan pemerintah dan sebagainya. Penelitian Natalia (2018) menemukan bahwa faktor paling dominan yang menyebabkan keterlambatan proyek di Kota Padang adalah faktor distribusi material.

Penelitian Khaidir (2018) tentang faktor yang paling berpengaruh sebagai penyebab keterlambatan pelaksanaan proyek pengairan pada Balai Wilayah Sungai Sumatera V di Sumatera Barat menemukan bahwa penyebab keterlambatan adalah izin tempat yang lambat oleh Pemda, permasalahan dengan lingkungan sekitar, kondisi cuaca, peningkatan harga-harga material, keterlambatan pengiriman material oleh supplier, ketidaktepatan waktu pemesanan, suplai tenaga kerja lambat, produktifitas tenaga kerja kurang, serta pengalaman tenaga kerja yang rendah. Faktor lain yang menghambat pekerjaan saat ini adalah merebaknya pandemi penyakit covid-19. Banyak proyek konstruksi yang terhenti pengerjaannya akibat pandemi ini. Hal ini terjadi karena industri konstruksi saling ketergantungan dengan sektor usaha lain. Penyedia jasa kontruksi juga menerima imbas keadaan ini dengan penghentian aktivitasnya.

Proyek renovasi sarana dan prasarana sekolah adalah pekerjaan konstruksi yang di danai oleh anggaran penerimaan belanja negara (APBN) tahun 2020 di bawah koordinasi Kementerian Pekerjaan Umum dan Perumahan Rakyat. Keunikan proyek ini adalah satu paket 
pekerjaan terdapat banyak lokasi. Untuk Kabupaten Pasaman Barat, jumlah lokasi pekerjaan sebanyak 15 (lima belas) Sekolah Dasar dengan rentang jarak lebih dari $100 \mathrm{Km}$ dan akses jalan ke masing-masing lokasi pun tidak semuanya baik. Kontraktor pelaksana merupakan perusahaan konstruksi yang beralamat di Kota Jakarta. Komponen material dan peralatan yang di gunakan sebagian di datangkan dari luar daerah. Pelaksanaan pekerjaan konstruksi di mulai pada awal tahun 2020, dimana sedang diberlakukan masa pembatasan sosial berskala besar (PSBB) akibat berkembangnya wabah penyakit covid-19 di Provinsi Sumatera Barat. Kondisi geografis dan sosial menjadi kendala tersendiri bagi Kontraktor dalam pelaksanaan pekerjaan secara tepat waktu. Proyek ini mengalami keterlambatan dengan melakukan 2 (dua) kali addendum perpanjangan waktu pelaksanaan. Pada penelitian kali ini akan di tinjau penyebab keterlambatan pelaksanaan proyek..

\section{TINJAUAN PUSTAKA}

\section{Kontrak Konstruksi}

Pengertian Pekerjaan Konstruksi berdasarkan Undang- undang Jasa Konstruksi No. 2 tahun 2017 adalah keseluruhan atau sebagian kegiatan yang meliputi pembangunan, pengoperasian, pemeliharaan, pembongkaran, dan pembangunan kembali suatu bangunan. Hal yang mengatur mengenai hubungan kerja antara Penggunan Jasa (Owner) dengan Penyedia Jasa (Kontraktor, Konsultan) adalah Kontrak Kerja Konstruksi. Perjanjian yang mengikat antara pemilik proyek dengan pelaksana proyek tersusun dalam kontrak kerja konstruksi berdasarkan hasil dari pengajuan penawaran harga dan hasil kesepakatan negosiasi untuk melaksanakan pekerjaan konstruksi berdasarkan perencanaan gambar dan spesifikasi teknis rencana yang dibatasi oleh biaya dan waktu pelaksanaan penyelesaian pekerjaan. Hal ini tertuang dalam suatu dokumen yang berisi persyaratan kontrak, spesifikasi, gambar, BQ, penawaran harga, surat penunjukan dan surat perjanjian.

Ketentuan mengenai isi kontrak kerja konstruksi terdapat pada Pasal 22 Undang-undang Nomor 18 Tahun 1999 tentang Jasa Konstruksi, dimana kontrak kerja konstruksi sekurangkurangnya harus memuat mengenai:

1. Para pihak (Pengguna Jasa dan Penyedia Jasa), yang memuat secara jelas identitas para pihak.

2. Rumusan pekerjaan. Bagian ini berisikan tentang uraian yang jelas dan rincian tentang lingkup kerja, nilai pekerjaan, batasan waktu pelaksanaan.

3. Masa pertanggungan dan/atau pemeliharaan, yang memuat tentang jangka waktu pertanggungan dan/atau pemeliharaan yang menjadi tanggung jawab penyedia jasa.

4. Tenaga ahli, berisi kualifikasi dan jumlah tenaga ahli yang diperlukan untuk melaksanakan pekerjaan konstruksi. 
5. Hak dan kewajiban Penggunan Jasa dan Penyedia Jasa, yang berisi tentang hak pengguna jasa untuk memperoleh hasil pekerjaan konstruksi serta kewajibannya untuk memenuhi ketentuan yang diperjanjikan serta hak penyedia jasa untuk memperoleh informasi dan imbalan jasa serta kewajibannya melaksanakan pekerjaan konstruksi.

6. Cara/metode pembayaran, yang memuat tentang kewajiban pengguna jasa dalam melakukan pembayaran hasil pekerjaan konstruksi.

7. Cidera janji, berisikan tentang tanggung jawab apabila pengguna jasa atau penyedia jasa tidak melaksanakan kewajibannya sesuai dengan yang tertuang dalam kontrak.

8. Penyelesaian perselisihan, yang memuat ketentuan tentang tata cara penyelesaian perselisihan akibat ketidaksepakatan.

9. Pemutusan kontrak kerja konstruksi, yang memuat ketentuan tentang pemutusan kontrak kerja konstruksi yang timbul akibat tidak dapat dipenuhinya kewajiban salah satu pihak.

10. Keadaan memaksa (force majeure), yang memuat ketentuan tentang kejadian yang timbul di luar kemauan dankemampuan para pihak, yang menimbulkan kerugian bagi salah satu pihak.

11. Kegagalan bangunan, yang memuat ketentuan tentang kewajiban penyedia jasa dan/atau pengguna jasa atas kegagalan bangunan.

12. Perlindungan pekerja, yang memuat ketentuan tentang kewajiban para pihak dalam pelaksanaan keselamatan dan kesehatan kerja serta jaminan tenaga kerja.

13. Aspek lingkungan, yang memuat kewajiban para pihak dalam pemenuhan ketentuan tentang lingkungan.

\section{Penyebab Keterlambatan Proyek}

Penyebab Keterlambatan Proyek menurut Wirabakti (2014), keterlambatan proyek konstruksi di pengaruhi oleh faktor-faktor sebagai berikut:

1. Faktor Tenaga Kerja

Adapun hal yang berhubungan dengan tenaga kerja adalah kurangnya keahlian tenaga kerja, kurangnya kedisiplinan tenaga kerja, kurangnya motivasi kerja para pekerja, kurangnya kehadiran tenaga kerja, kurangnya ketersediaan tenaga kerja, penggantian tenaga kerja baru, dan buruknya Komunikasi antara tenaga kerja dan badan pembimbing.

2. Bahan/Material

Dalam penyediaan material, biasanya terdapat kendala: keterlambatan pengiriman bahan, ketersediaan bahan terbatas di pasaran, kualitas bahan jelek, kelangkaan material yang 
dibutuhkan, adanya perubahan material oleh Owner, kerusakan bahan di tempat penyimpanan.

3. Karakteristik tempat

Kondisi dan keadaan lokasi proyek juga berpengaruh terhadap keterlambatan proyek, seperti: keadaan permukaan dan di permukaan bawah tanah, tanggapan dari lingkungan sekitar proyek, karakter fisik bangunan sekitar proyek, tempat penyimpanan bahan/material, akses kelokasi proyek yang sulit, kebutuhan ruang kerja yang kurang serta lokasi proyek yang jauh dari pusat kota/pusat distribusi peralatan dan material.

4. Manajerial

Aspek manajerial juga sangat mempengaruhi keterlambatan proyek, yang meliputi aspek: pengawasan proyek, kualitas pengontrolan pekerjaan, pengalaman manajer lapangan, perhitungan kebutuhan, komunikasi antara konsultan dan kontraktor, lomunikasi antara kontraktor dan pemilik, kesalahan manejemen material dan peralatan.

5. Peralatan

Hal-hal yang mempengaruhi keterlambatan proyek dari segi peralatan adalah ketersediaan peralatan, kerusakan peralatan, kualitas peralatan yang buruk dan produktivitas peralatan.

6. Keuangan

Keberlangsungan pelaksanaan proyek di dukung oleh pendanaan yaitu pembayaran dari owner, harga bahan/material yang mahal, alokasi dana yang tidak cukup, telatnya pembayaran kepada pekerja.

\section{Fisik Bangunan}

Cepat atau lambatnya pengerjaan proyek juga tergantung dari luas wilayah, jumlah unit dan jumlah lantai.

8. Desain

Aspek perencanaan yang meliputi desain yang memperlambat penyelesaian pekerjaan antara lain : perubahan desain oleh pemilik, kesalahan desain oleh perencana, ketidak lengkapan gambar desain, keterlambatan pemberian detail gambar, kerumitan desain.

\section{Cuaca}

Kondisi cuaca pun bisa memperlambat penyelesaian proyek, faktor intensitas curah hujan, cuaca panas dan perubahan kondisi cuaca.

10. Kejadian yang tidak terduga (force majeure)

Hal-hal yang di luar kuasa Penggunan Jasa dan Penyedia Jasa, seperti : kerusuhan, bencana alam, pemogokan buruh, kecelakaan.

11. Kebijakan pemerintah 
Antara lain adanya kenaikan BBM. nilai tukar mata uang, dan kondisi lain yang menyebabkan pemerintah mengeluarkan aturan-aturan baru.

\section{METODE}

Penelitian ini menggunakan metoda deskriptif, dimana penelitian deskriptif adalah penelitian yang bersifat menggambarkan suatu fenomena, peristiwa, gejala baik menggunakan data kuantitatif maupun kualitatif. Pengumpulan data dilakukan secara kuisioner dan wawancara. Kuisioner diberikan kepada Kontraktor, Konsultan MK dan Owner. Kuisioner disusun berdasarkan studi literatur tentang penyebab keterlambatan proyek dan di berikan nilai berdasarkan Skala Likert dengan nilai 1-5. Selanjutnya hasil dari kuisioner di hitung rata-rata secara statistik. Kemudian dilakukan wawancara kepada seluruh stakeholder untuk peninjauan ulang dari kompilasi jawaban kuisioner. Hasil kuisioner dan wawancara akan di tuangkan dalam analisis dan pembahasan serta di ambil kesimpulan tentang penyebab keterlambatan proyek. Data hasil kuisioner di hitung rata-ratanya dengan menggunakan rumus :

$$
\begin{aligned}
& \quad \quad X \text { rata }- \text { rata }=\frac{X 1+X 2+X 3+X 4+\cdots}{\Sigma x i} \\
& X 1=\text { Variabel } 1 \\
& X 2=\text { Variable 2, dst } \\
& \Sigma X i=\text { Jumlah keseluruhan variabel }
\end{aligned}
$$

Dari nilai rata-rata variabel, akan di urutkan dari nilai terbesar ke nilai terkecil. Kesimpulan penyebab keterlambatan proyek di ambil dari 5 (lima) urutan nilai tertinggi dari jawaban responden.

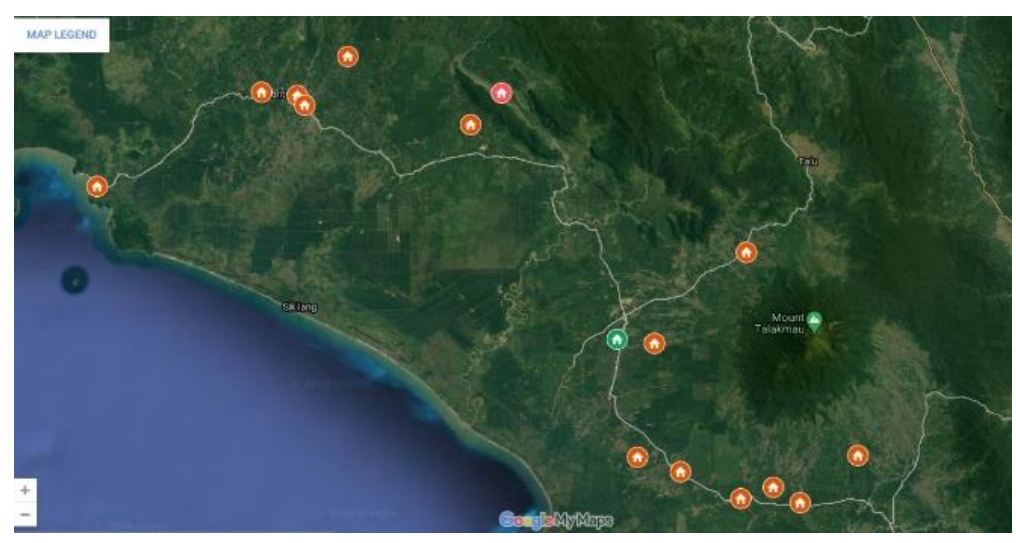

Gambar 1. Sebaran Lokasi Pekerjaan

\section{HASIL}

\section{Hasil Jawaban Kuisioner Responden}

Dari jawaban responden terhadap kuisioner dapat di lihat pada tabel di bawah ini : 
Tabel 1. Rata-rata hasil jawaban responden

\begin{tabular}{ccc}
\hline No & Uraian & $\begin{array}{c}\text { Jawaban Responden } \\
\text { (Rata-rata) }\end{array}$ \\
\hline 1 & Tenaga Kerja & 2,67 \\
2 & Material & 2,00 \\
3 & Karakteristik tempat & 2,00 \\
4 & Manajerial & 1,67 \\
5 & Peralatan & 1,00 \\
6 & Keuangan & 1,33 \\
7 & Fisik Bangunan & 1,00 \\
8 & Desain & 3,67 \\
9 & Cuaca & 2,00 \\
10 & Kejadian yang tidak terduga (Force Majeure) & 4,67 \\
11 & Kebijakan pemerintah & 4,00 \\
\hline
\end{tabular}

\section{Pembahasan}

Dari tabel di atas, di peroleh penyebab keterlambatan proyek sebagai berikut:

1. Kejadian yang Tidak Terduga (Force Majeure).

Salah satu pasal yang harus di cantumkan pada kontrak konstruksi adalah mengenai kejadian tidak terduga atau dikenal dengan force majeure. Salah satu kebijakan yang di keluarkan sehubungan dengan pandemi ini adalah Keputusan Presiden No. 11 tahun 2020 yang menyatakan bahwa Indonesia sedang dalam masa darurat kesehatan masyarakat karena terjadinya penyebaran virus Covid-19. Peraturan ini dikeluarkan disebabkan pertumbuhan angka pasien penderita covid-19 yang berkembang cepat dari waktu ke waktu dan menjangkau lintas wilayah, lintas negara serta menyebabkan dampak yang besar terhadap aspek ekonomi, social, politik dan budaya. Peraturan Pemerintah No. 21 Tahun 2020 tentang Pembatasan Sosial Berskala Besar (PSBB) juga di keluarkan dan di ikuti oleh peraturan daerah masing-masing. Peraturan ini memberikan penjelasan tentang persyaratan bagi Kepala Daerah yang ingin menerapkan PSBB di wilayahnya dan di wajibkan mendapat persetujuan dari Menteri Kesehatan. Di Provinsi Sumatera Barat juga di berlakukan Pembatasan Sosial Berskala Besar (PSBB) yang di mulai dari tanggal 22 April hingga pada tanggal 5 Mei 2020 sesuai dengan keputusan Gubernur Sumatera Barat Nomor: 180-297-2020 dalam rangka percepatan penanganan corona virus disease 2019 (covid-19). Kemudian PSBB diperpanjang hingga 29 Mei, dan diperpanjang lagi hingga 7 Juni. PSBB membatasi pergerakan masyarakat yang menyebabkan pergerakan orang dan barang sangat 
terbatas. Setelah itu, terjadi masa PSBB transisi yang masih membatasi pergerakan masyarakat. Hal ini menyebabkan Kontraktor sulit untuk pengadaan tenaga kerja dan material.

\section{Kebijakan Pemerintah}

Terjadinya pandemi covid-19 menyebabkan pemerintah mengeluarkan tambahan anggaran dana bidang kesehatan. Pemberlakukan PSBB juga mengharuskan pemerintah memberikan bantuan stimulan sebagai pengganti biaya hidup masyarakat yang matapencahariannya terdampak. Hal ini mengakibatkan pemangkasan anggaran, termasuk anggaran infrastruktur. Selain itu, perumusan kebijakan anggaran membutuhkan waktu yang cukup lama. Pada proyek ini, tidak terjadi pemotongan anggaran maupun volume pekerjaan dengan asumsi pemerintah proyek sudah terkontrak sebelum pandemi terjadi. Namun dibutuhkan waktu \pm 60 hari kalender sampai pengesahan keputusan. Selama masa ini, kontraktor ragu-ragu melanjutkan pekerjaan.

3. Desain

Proyek ini di rencanakan oleh Konsultan Individu yang di rekrut langsung oleh Owner. Perencanaan ini dilakukan pada tahun 2017 dan waktu perencanaan pun singkat. Pada proyek ini, stakeholder yang terlibat juga cukup banyak. Koordinasi dilakukan dengan Dinas Pendidikan serta Sekolah yang akan di renovasi. Banyak terjadi perubahan di lokasi pekerjaan seperti ada bangunan yang sudah di perbaiki dan tambahan kerusakan bangunan yang membutuhkan perubahan desain. Selain itu juga ada perubahan kebijakan untuk bangunan baru dan pagar bangunan. Selain itu, warga masyarakat sekitar sekolah juga mengajukan berbagai permintaan. Hal ini harus di akomodir dengan melakukan rapat koordinasi melibatkan stakeholder terkait. Perubahan addendum untuk desain dilakukan sebanyak 2 (dua) kali.

4. Tenaga Kerja

Salah satu kesulitan Kontraktor dilapangan adalah kurangnya tenaga kerja terampil. Untuk mendatangkan tenaga kerja dari luar daerah tidak memungkinkan karena PSBB akibat pandemi covid-19. Akibatnya pekerjaan berjalan dengan lambat. Penambahan tenaga kerja luar hanya bias di lakukan di akhir masa kontrak.

5. Cuaca, Karakteristik Tempat dan Material

Pada akhir masa pelaksanaan proyek, cuaca cenderung hujan. Hal ini sedikit memperlambat pekerjaan. Distribusi material pun terlambat. Lokasi pekerjaan yang menyebar di 15 (lima belas) titik juga menjadi tantangan tersendiri bagi kontraktor. Dari 
tabel di bawah ini dapat di lihat jarak pengantaran material dari Kantor Kontraktor di

\begin{tabular}{|c|c|c|c|c|c|}
\hline pusat & No & Lokasi & $\begin{array}{l}\text { Jarak } \\
(\mathbf{K m})\end{array}$ & $\begin{array}{c}\text { Waktu } \\
\text { Tempuh } \\
\text { (menit) }\end{array}$ & \multirow{16}{*}{$\begin{array}{c}\text { Waktu Tempuh } \\
\text { dari Gudang }\end{array}$} \\
\hline \multirow{15}{*}{$\begin{array}{l}\text { Tabel 2. Jarak dan } \\
\text { Lokasi Pekerjaan } \\
\text { (Kantor) }\end{array}$} & 1. & SDN 19 Kinali & 39 & 53 & \\
\hline & 2. & SDN 25 Kinali & 29 & 34 & \\
\hline & 3. & SDN 02 Kinali & 23 & 27 & \\
\hline & 4. & SDN 36 Kinali & 27 & 33 & \\
\hline & 5. & SDN 38 Kinali & 14 & 19 & \\
\hline & 6. & SDN 11 Pasaman & 4 & 6 & \\
\hline & 7. & SDN 16 Talamau & 17 & 30 & \\
\hline & 8. & SDN 14 Gunung Tuleh & 31 & 45 & \\
\hline & 9. & SDN 03 Gunung Tuleh & 43 & 90 & \\
\hline & 10. & SDN 14 Lembah Melintang & 49 & 66 & \\
\hline & 11. & SDN 15 Lembah Melintang & 49 & 67 & \\
\hline & 12. & SDN 07 Lembah Melintang & 51 & 70 & \\
\hline & 13. & SDN 11 Koto Balingka & 54 & 75 & \\
\hline & 14. & SDN 09 Sungai Aur & 52 & 77 & \\
\hline & 15. & SDN 05 Sungai Beremas & 76 & 120 & \\
\hline
\end{tabular}

Pada masa awal pandemi covid-19, kontraktor kesulitan dalam mendistribusikan material ke lokasi pekerjaan. Pada sebagian lokasi, masyarakat setempat tidak memberikan izin orang luar (bukan berdomisili setempat) untuk masuk ke lokasi.

\section{SIMPULAN}

Dari analisa data di atas, maka dapat di tarik kesimpulan faktor penyebab terjadinya keterlambatan pekerjaan sebagai berikut:

1. Kejadian yang Tidak Terduga (Force Majeure).

2. Kebijakan Pemerintah

3. Desain

4. Tenaga Kerja

5. Cuaca, Karakteristik Tempat dan Material

\section{DAFTAR PUSTAKA}

Hassan, Haekal. 2016. Faktor-faktor Penyebab Keterlambatan Pada Proyek Konstruksi Dan Alternatif Penyelesaiannya (Studi Kasus: Di Manado Town Square III). Jurnal Sipil Statik Universitas Sam Ratulangi Vol.4 No.11 November 2016.

Khaidir, Indra. 2018. Faktor Penyebab Keterlambatan Pelaksanaan Proyek Konstruksi Di Sumatera Barat. Jurnal Rekayasa Vol. 8, No. 01 tahun 2018. 
Messah Y, Widodo T, Adoe M. 2013. Kajian Penyebab Keterlambatan Pelaksanaan Proyek Konstuksi Gedung Di Kota Kupang. Jurnal Teknik Sipil Universitas Kristen Petra, Vol. II, No. 2, September 2013.

Natalia, Monika dkk. 2018. Faktor Penyebab Kegagalan Akibat Keterlambatan Proyek Konstruksi Pada Bangunan Gedung di Kota Padang. Jurnal Ilmiah Rekayasa Sipil Vol. XV No. 2 Edisi Oktober 2018

Soeharto, Imam, "Manajemen Proyek Dari Konseptual Sampai Operasional”. Erlangga. Jakarta. 1995.

Sudjana N dan Ibrahim R. 1989. Penelitian dan Penilaian Pendidikan. Sinar Baru Algesindo, Bandung.

Sulaiman M, Munirwansyah, Azmeri. 2017. Analisis Penyebab Keterlambatan Pelaksanaan Proyek Ditinjau Dari Waktu Pelaksanaan Di Provinsi Aceh. Jurnal Ekonomi Transportasi, Manajemen Konstruksi Dan Perencanaan Wilayah vol 1 No. 2 Desember 2017.

Sutan Syah, Mahendra Ir. Manajemen Proyek. Gramedia Pustaka Utama, Jakarta, 2004.

Undang-Undang Jasa Konstruksi No. 2 Tahun 2017

Vitri, Gusni. 2020. Pola Rantai Pasok Material Pada Proyek Renovasi Sarana Dan Prasarana Sekolah Kabupaten Pasaman Barat. Journal of Civil Engineering and Vocational Education Vol. 7 No. 3 September 2020

Waluyo, Rudi. 2014. Kajian faktor penyebab keterlambatan waktu pelaksanaan proyek konstruksi. Jurnal media komunikasi Teknik Sipil Vol. 17, No. 2 Desember 2014.

Yasin, Nazarkhan. 2006. Mengenal Kontrak Konstruksi di Indonesia. PT. Gramedia Pustaka Utama, Jakarta. 